\title{
The impact of Location-based Marketing strategies on retail sectors in Al Batinah region during COVID 19 Pandemic \\ Shantanu Shekhar ${ }^{1 *}$, Kumaresan Chandrasekaran ${ }^{2}$, Joshy Mathew ${ }^{3}$ \\ ${ }^{1 * 2,3}$ Lecturer, Business Studies Department, University of Technology and Applied Sciences - Al Musanna, Oman. Email: ${ }^{1 *}$ shantanushekhar123@ rediffmail.com, ${ }^{2}$ kumaresanbdu@gmail.com, ${ }^{3}$ joshimtw@ hotmail.com
}

\author{
Keywords \\ Location Based Marketing, Social Media, Mobile \\ Marketing, LBM Tools, Covid 19 Pandemic, \\ Oman. \\ Article History \\ Received on $4^{\text {th }}$ August 2021 \\ Accepted on $31^{\text {st }}$ August 2021 \\ Published on $23^{\text {rd }}$ September 2021 \\ Cite this article \\ Shekhar, S., Chandrasekaran, K., \& Mathew, J. \\ (2021). The impact of Location-based Marketing \\ strategies on retail sectors in $\mathrm{Al}$ Batinah region \\ during COVID 19 Pandemic. International Journal \\ of Management, Innovation \& Entrepreneurial \\ Research, 7(2), 07-17. \\ https://doi.org/10.18510/ijmier.2021.722
}

Copyright @Author

Publishing License

This work is licensed under a Creative Commons Attribution-Share Alike 4.0 International License

\begin{abstract}
Purpose: Location-based marketing has become an essential component in today's businesses. The principal objective of this study is to investigate the growing significance of using location-based marketing services to small and medium-scale marketers and customers.
\end{abstract}

Methodology: This is an exploratory study, which aims to explore the impact of location-based marketing on the retail sector of the Al Batinah region in the Sultanate of Oman.

Main Findings: Social media platforms play an important role in the Location-Based marketing of various retail sectors such as SME's and these platforms play a major role in helping retailers to make decisions whether they wish to market their products by using this platform or not.

Implications: All organizations' top-level management must focus on data mining to identify the right customers and at the same time they should focus on innovative marketing strategies on LBS.

Novelty: This study provides motivations and insights that drives businesses and customers to use these LBM services.

\section{INTRODUCTION}

Location-Based (or Location-Specific) Services (LBS) have been discussed in the trade press and conferences for some time now. It is considered as the main thrust behind M-commerce by many business leaders. Various location-based service tools are used by leading brands in the market.

LBS defines those mobile commerce services that utilize information about the current location of the person using a mobile device. Ideally, the information provided should be both location-specific and personalized based on the personal profile of the user. Location-based services can be categorized into two possible categories based on the perspective of the user:

- End-User Application Perspective: Traffic and weather information based on user location, driving directions, entertainment applications, wireless advertising, store location, etc. See more under Applications

- Developer \& vendor perspective: mapping, routing (Directions), GPS Navigation (real-time turn-by-turn navigation), proximity searches, destination guides, tracking (E-911, vehicles, assets, friend or buddy finders), telematics, locationbased billing, advertising, etc.

\section{How It Works}

Many methods are used to identify the position of the user. These methods include "GPS (Global Positioning System, a network of satellites operated by the U.S. Department of Defense), cell site triangulation, network-assisted GPS, manual determination (find an address, place, point of interest, or position on a map), or combination approaches".

In wireless location-based service applications, the position of the user is transmitted with some additional identifying information (Vehicle ID, handset ID, user ID) to an application in a server that may reside inside or outside the carrier's network. Position information, usually in terms of a latitude/longitude pair (or sometimes, a postal code for a cell site), is sent to the application in a server or back to the client device, sometimes through a middleware, which manages the security and quality of a wirelessly determined position. The application typically presents the position information in terms of a current or historical position on a map or route.

The location information may be further tied to a database of services - restaurants, hotels, or stores that may want to send an advertising message or a coupon to the consumer. Starting here, the scope of utilization is simply up to the creative mind of technology and business designers. 


\section{Role of Location-Based Services in M-Commerce}

Location-based services will initially be used primarily to get or find people to or at bricks and mortar locations, locationbased services should make certain kinds of m-commerce, like ticket purchases, easier and more relevant to end-users buying over their wireless devices.

Products and Services: GPS and other position determination chipsets; GPS receivers and position enhanced handsets, radios, PDA's and receivers; position determination network equipment (PDE), Mobile Positioning Center (MPC); enabling, middleware and carrier infrastructure software and services, end-user and enterprise, applications.

\section{Applications - Consumer \& Enterprise Perspective}

There are hundreds of LBS applications that are announced almost daily. Some of these applications are:

- Destination guides with maps, directions.

- Location-Based Traffic and Weather Alerts.

- Wireless advertising and electronic coupons.

- Movie, theatre, and restaurant location and booking.

- Store (offering cheapest prices for brand-name items) location applications.

- Personal Messaging (Live Chat with Friends).

- Information Services (News, Stocks, Sports).

- Personalized Content: Wireless portals may have personal information about the preferences of a subscriber and may serve (by push) relevant content to that subscriber. In yet another implementation, the subscriber may obtain (by pull) content that is of interest to him/her.

Enterprise applications usually involve vehicle tracking but may also include navigation. E-911 implementation for public safety is an FCC-mandated service.

\section{Social Media Marketing}

Social media is quickly becoming one of the most important aspects of digital promotion, which provides incredible benefits that help reach millions of customers worldwide. Furthermore, on the off chance that you are not applying this profitable source to your venture, you are missing an incredible marketing opportunity, as it streamlines the process of spreading the word about your product and mission.

Social media can be used to increase your business visibility. To get started, create social media profiles for your business and start networking with others. By applying a social media strategy, it will help you significantly increase your brand recognition. By spending only a few hours per week, over $91 \%$ of marketers claimed that their social marketing efforts greatly increased their brand visibility and heightened user experience. Undoubtedly, having a social media page for your brand will benefit your business and with regular use, it can produce a wide audience for your business in no time.

It also helps in engaging and interacting with customers. The more you communicate with the audience, the more chances you have of conversion. Set up a two-way communication with your target audience so that their wishes are known, and their interest is catered with ease. Moreover, communication and engagement with customers is one of the ways to win their attention and convey your brand message. Thus, your brand will reach more audience in real terms and gets itself established without any hassle.

\section{LITERATURE REVIEW}

One of the major research in location-based marketing (He, Wenbo and Liu, Xue and Ren, Mai, 2011), explored the areabased organizations use the topographical situation to propel customer experiences in a variety of settings, including areabased search and area-based versatile publicizing. To attract more customers, the region-based compact casual association organizations give genuine prizes to the customer, when a customer checks in at a particular setting or region. This gives an impulsion for customers to subvert their regions. Furthermore, it motivates the clients to undermine their areas. (He, Wenbo \& Liu, Xue \& Ren, Mai, 2011) notes that through true analyses on foursquare, the leading location-based social network, exhibits that our attacking approach functions true to form; and location cheating threatens the development and deployment of location-based mobile social network services.

In the present environment, consumers are more fragmented than any other time and marketers are looking for alternative and innovative ways for elective and creative approaches to acquire individuals' consideration and interface with these pieces. As a smartphone user, the conceivable outcomes of Location Based Marketing (LBM) on cell phones are being stretched out which makes it simpler to convey administrations. Advertisers should dispatch LBM administrations since it permits them to foster inventive applications and administrations to give a superior client experience. (Jaradat, A., Mohamad, N. A., Asadullah, A., Ebrahim, S. (2015)). 
As indicated by (Jaradat, A., Mohamad, N. A., Asadullah, A., Ebrahim, S. (2015)) region-based promotion and showcasing is laying down profound roots and will give associations one more street to interface with their customers efficiently and more speedily. Associations that embrace it will be lither than their opponents while those that don't will be deserted. Region-based adaptable promotion accomplishes the amalgamation of online displaying and genuine shopping experience.

\section{Changes in Consumer Behavior during COVID-19}

According to the examination by (Larisa Bedgood, 2020), preceding the COVID-19 pandemic, 67\% of customers said brands need to do more to coordinate their purchaser's decisions on the web and supported visiting a real store to choose a purchase. This is as shown by a new investigation by ZOOVU. Clearly, the pandemic has extensively changed client enactment. Buyers are essentially shopping on innovative channels and actual store visits have powerfully declined. Purchasers are furthermore looking for different kinds of help, every now and again dictated by more current sorts of development. Overall, what definitively one can ponder upon is, "are the purchasers looking for, and is it possible that brands can battle and remain significant among technologically driven clients?" Web-based Shopping Has Increased Exponentially

Quarantines, store closings, and changing attitudes have left many stores empty and more and more consumers are heading to online sites for their purchases. Changes in consumer behaviors that we have seen over the last several months include:

- $28 \%$ are making online purchases they usually would make in-store

- $25 \%$ are buying products they otherwise would not buy

- $22 \%$ are spending more time on online shopping

In additional research, (Larisa Bedgood, 2020) these findings were a common theme with 56\% of consumers saying they increased online shopping during the pandemic and 14\% stating they have made purchases for the first time.

\section{How has the coronavirus outbreak affected consumers' online shopping?}

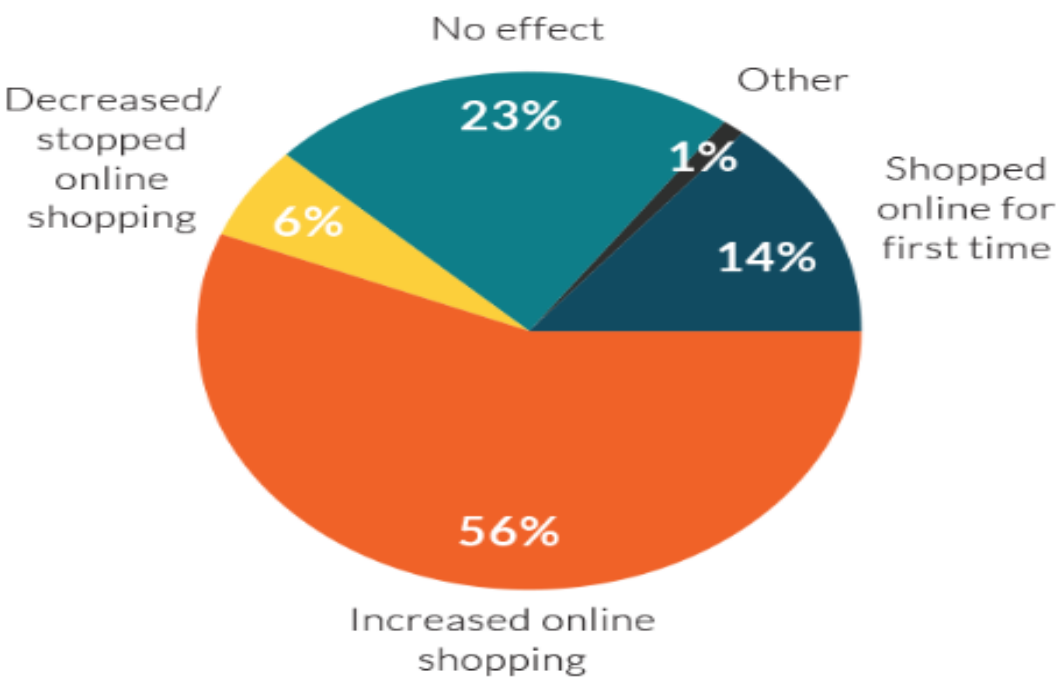

Figure 1: How has the coronavirus outbreak affected customer's online shopping?

Source: https://www.business2community.com/consumer-marketing/changes-in-consumer-behavior-during-covid-19$\underline{02331693}$

What do Consumers Expect Today?

- Support \& Assistance: $64 \%$ believe it's important for brands to provide them with guidance.

- Confidence in purchases: 55\% think it's very or extremely important for brands to support them in making the right purchase decision.

- Simplified Choice: $84 \%$ wish search identified their needs and narrowed down results to 5-10 choices.

- Personalization: $70 \%$ want brands to interact with them on a personal level.

CMOs are also weighing in how they see their customers' behaviors changing. In research by the CMO Survey, the biggest change for nearly $97 \%$ of respondents has been lower in-person marketing engagement as fewer people visit stores to attend events. 


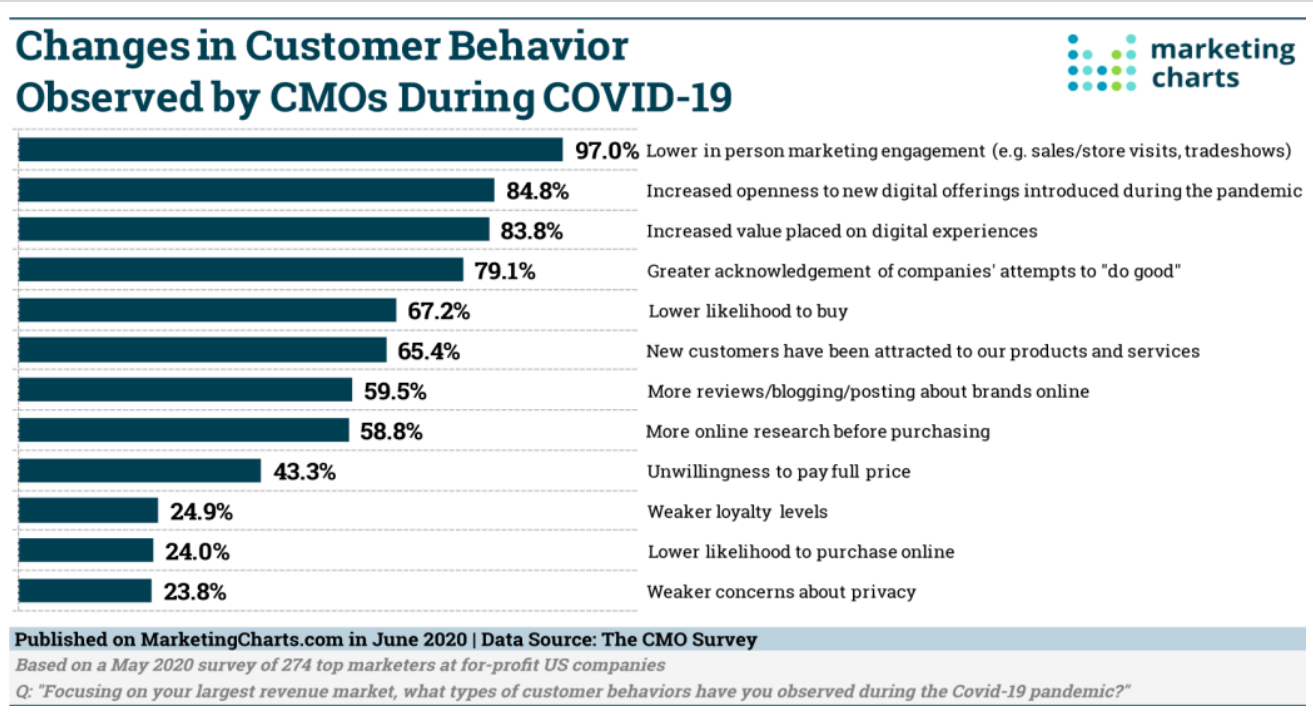

Figure 2: Changes in customer behavior observed by CMOs during COVID 19

Source: https://cmosurvey.org/wp-content/uploads/2020/06/The_CMO_Survey-Highlights-and_Insights_Report-June-

While the decrease in customer visits may be obvious, other areas of change include:

$84.8 \%$ - Increased openness to new digital offerings introducing during the pandemic.

$83.8 \%$ - The increased value placed on digital experiences.

$79.1 \%$ - A greater acknowledgment of companies' attempt to do good.

While $67.2 \%$ reported a lower likelihood to buy, this is offset some with $65.4 \%$ reporting that new customers have been attracted to their products and services.

\section{Privacy and location-based marketing}

(Handly, B. (2019)) takes note that brands and associations using region-based elevating should perceive how these crowds are made, and how customer security is guaranteed. An essential development is ensuring that the region data used, whether or not it was obtained from GPS or another sign, is picked in, and that the buyer understands that they are choosing in to impart region to help present to advancing. Most, if not all, the space-based promotion follows this preparation today and holds fast to sets of acknowledged principles from various industry social affairs. The data should reliably be collected and anonymized to maintain seclusion. Promoters like to show up to a large number inside their goal market. One more way to ensure security is not using region-based groups from "fragile" regions, for instance, anything related to clinical benefits. There may be an exception if the client has given express consent for this specific use in a particular case. Any fruitful mission will depend on numerous various systems and strategies to be effective.

LBS improves people's abilities to get to exercise and others by making the world more effective, discoverable, traversable, intelligent, altered, agreeable, and safe. Notwithstanding, LBS can similarly add to the issues of going up against an amassed and urbanized world by enabling crevasse transportability. By the year 2030, the quantity of vehicles on the planet will inflate from around one billion to over 2.5 billion (Sperling and Gordon, 2009). The aim of area-based advertising through cell phones is to support those exercises inclusive of drive pedestrian activity, share limits, and assemble client reliability. Cell phones have been utilized to accumulate data about close by organizations including surveys, bearings, calling the business, and utilizing the organizations' versatile application. With area-based versatile promoting, the business is not difficult to track down and has easily consolidated location-based showcasing with an in general designated advertising approach that incorporates online media, message pop-ups, email bulletins, and furthermore disconnected showcasing. (Yim, J., Ganesan, S., Kang, B.H. (2017))

This research (Bauer, Christine \& Strauss, Christine, 2016) discusses the LBA is recognized for static roadside billboards and the Web, LBA can now be found on mobile devices. This mobile advertising adds valuable opportunities for companies: It allows consumers to be addressed (i) individually, (ii) based on their current location, and (iii) dynamically in real-time; furthermore, (iv) content may be replaced quickly by remote access. Accordingly, within the mobile marketing domain, LBA on mobile devices turns over a new leaf.

The inaudibility of cell phones and smartphones engage marketing experts to contact customers autonomously at whatever point and any spot. Correspondingly, devices are normally furnished with GPS value and various sensors, marketing specialists get the opportunity to give elevating messages uniquely crafted to a client's region just as picking places for message movement is known to have a high and positive impact on advertising. (Bauer, Christine, and Strauss, Christine, 2016). 
The above conversation plainly expresses that LBM is the recent fad in Marketing Communication to recognize possible customers. This innovation helps any business association - regardless of whether it is SMEs, retailers, and some other specialist co-ops to target possibilities dependent on their topographical area/vicinity, and impart them by means of notices, push messages, and customized advertisements by offering exceptional rewards and modified administrations.

Smartphones have become an integral part of human life; it is with them wherever they go. People search, identify and analyze information related to any product, service, retailer, any business organization, working hours and make decisions using their smartphones. Therefore, GPS activated smartphone is the key tool used in LBM to identify and attract new clients.

As per the article by (Larisa Bedgood, 2020) online shopping has_increased more rapidly. Covod 19 Pandemic is not a setback for retailers but it's an opportunity to move from a traditional to a digital platform or blending both. In this new scenario, LBM has a great role in sending the right message to the right client.

This new research (Bernritter, S.F., Ketelaar, P.E. \& Sotgiu, F. 2021) discusses the importance of LBMM. Marketing staff uses the orientation for the behavior of Location-Based Mobile Marketing (LBMM). However, a very personalized marketing message can be counterproductive by inducing consumer reactance. It is recommended that the effectiveness of LBMM can minimize the reactance of consumers, which can be achieved by effectively combining location targeting (instore vs. outstore), behavioral targeting (based on consumers' product category involvement [PCI]), and the type of promotion offered (price vs. non-price promotion). The results of the field surveys, virtual reality experiments, and two online experiments indicate that mobile ads are usually effective in increasing sales of those mobile advertising contours, but this is the consumer only if there is a low PCI with categories of announced products. This reduces its reactance. To attract consumers to stores, companies indicate that companies must provide low PCI promotions and consumer prices with non-standard promotions. Therefore, the possibility of purchase is high.

This study (Bernritter, S.F., Ketelaar, P.E. \& Sotgiu, F. 2021) has explained with a suitable example of how location-based mobile marketing (LBMM) confront consumers every day. Real campaign examples based on Starbucks show that the brand could be selected from a series of guidance options by adopting an LBMM campaign. They should be directed to internal or external consumers of the stores depending on the behavior of their previous consumers and to provide specific advertising consumer segments.

This article (Chen, Jengchung \& Su, Bo-chiuan \& Yen, David. 2014)) explores the importance of the correlation between ad format, product engagement, privacy and brand credibility, and consumer attitudes towards location-based advertising. The relationship between attitudes towards location-based advertising and attitudes towards brands was also investigated. Location-based advertising greatly promotes a positive attitude towards location-based advertising. In addition, there is a statistically significant relationship between attitudes toward location-based advertising and attitudes toward brands.

Beacon is a promising innovation in the area of location-based marketing. This article (Moody, M. 2015) featured how Beacon-based correspondence can be investigated to advertisers. The investigation uncovered that the brands are cautious about customers' dithering and keep buyers' advantages on top of their minds. To add further, key and inventive area-based execution have an incredible potential to expand brand pertinence in the digital age.

Beacon technology is an important development in-store location-based marketing, which is used to send messages to customers in-store by the retailers. (Van de Sanden, S., Willems, K. \& Brengman, M. 2019))

The research paper (Uphaus, P., Beringer, B., Siemens, K., Ehlers, A., \& Rau, H. (2021)) has featured the potential outcomes of connecting location-based marketing to local and regional unexpected of interest by the Enterprises. This research uncovered that there is a huge absence of information about Location-based marketing. Location-based Marketing upgrade the client experience. Another system is genuinely necessary for investigating LBM to foster the market

(Tussyadiah, Iis. 2012) have deliberated in their research how location-based informal organization applications are equipped for producing market stimuli from the merchant, and therefore, contest-based and association-based prizes came about because of pertinence and network. They concentrated on location-based informal organization promotion meant for the real conduct that manifests in various behavior (ie. patronage to new places) and creates loyalty.

Discussed about and investigated how location-based marketing are profoundly successful than advertisements. The exploration (Khan V.-J., Ketelaar P., van 't Riet J., Konig R., Rozendaal E.,Batalas N. \& Markopoulos P., (2017)) affirmed that location-based promotion is especially liable to be compelling when the advertisement isn't just area compatible yet additionally applicable to shoppers' objectives. It is beneficial for sponsors to send local messages just when messages are pertinent.

In this article, (Bertini, M., \& Aydinli, A. (2020)) explore how the different types of conditional discounts can backfire in the point promotional favors. How the psychological reactance will affect the consumer product selections through various kinds of promotions? This article shows that the tactic can backfire in the sense that consumers spend less than they would in response to a standard discount. This effect does not generalize to traditional purchase requirements. This research work mainly helped identify the gap between the use and study of promotional favors. According to the authors (Bertini, M., \& Aydinli, A. (2020)), conditional discounts do not control what consumers can purchase. This article explores that the prediction highlights the various factors that the discretion of the firm or inherent to the consumers that they play a moderating role. 
In this research articles (Tsekouras, D., Dellaert, B. G. C., Donkers, B., \& Häubl, G. (2019)) explore the inherent relation between the presentation of a particular set of products and presenting a wider range of products and from which creating the attractiveness of the products which are closer to the consumer taste and preferences. i.e. fine product set granularity with coarse product set granularity. From this study, the authors explore the fine set granularity can maximize the attractiveness of the set of products. But the coarse product set granularity. The Coarse product set granularity makes it easier for the consumers to determine which of the recommended product is most attractive to them to select the product or increasing the consumer response. Evidence from a large-scale field study (with naturally occurring variation in the granularity of online recommendation sets) provides strong support for this tension and shows that less fine-grained product recommendation sets promote consumer response. We also find that, in line with our theorizing, coarser set granularity increases the time consumers spend processing detailed information about individual products relative to the time they spend comparing products at the set level. These effects are less pronounced when consumer engagement in the decision process is low. The key insights from the field study are replicated in a tightly controlled experiment (using a different product domain). The findings of this research have important implications for how best to integrate large online assortments and product recommendations to stimulate consumer response. This article explores the important managerial implications for the composition of the recommended sets in terms of fine product set granularity. We show that minor shifts in the product set granularity can have substantial effects on the firm's profitability.

Area-based versatile applications are getting more normal these days particularly in urban areas. A new report (Suzan Girginkaya Akdağ \& Ahu Ergen 2020) shows that area-based versatile applications are utilized by numerous advertisers to draw in new inhabitants and clients. It featured the job and capacity of area-based portable applications. Purchasers invest more energy on their cell phones; a central retailer's normal methodology is to target likely clients in nearness to its own area. However central (own) area focusing may tear apart benefits on inframarginal deals. This examination (Fong, N. M., Fang, Z., \& Luo, X. (2015)), exhibits the viability of cutthroat competition in focusing on location with respect to the act of elevating shoppers near a contender's area.

(Guido, Jorge Carlos Fiestas Lopez and Tuzovic, Sven, 2018) Innovations in technology and an expanding Omni channelretailing climate have on a very basic level changed how customers shop. In this unique situation, displaying is turning into a developing issue for retailers. While the expert press is plentiful with articles. Many examinations have researched determinants of showcasing products in an attempt to comprehend purchasers' inspirations and perspectives to display area. There are few studies on how physical shopping can be viably disturbed. Considering that proximity-marketing and areabased publicizing (LBA) are changing the manner in which buyers communicate with brands around them, the inquiry emerges on how area-based administrations can decrease the presence of showrooms.

Considering the growing significance of mobile technologies, this study (Law, R., Chan, I.C.C \& Wang, L. (2018)) collected and analyzed 92 related articles published in hospitality and tourism journals to examine the state-of-the-art research in this field. The comprehensive review shows that most studies focus on the context of tourism experience and the hotel industry.

Area Based Marketing (LBM) expands the pertinence of placed commercials by expanding consciousness of offers and accessibility in the shopper's vicinity. (Banerjee, S., Xu, S., and Johnston, S. D. 2021)). Nevertheless, contingent upon how it is executed, such publicizing can be seen as meddlesome, bothering, or an infringement of customer's security

\section{RESEARCH METHODOLOGY}

\section{Research Objectives}

- Impact of mobile marketing strategies like Social Media marketing and LBS in Oman.

- Changes in buying behavior by using mobile marketing strategies.

- Effectiveness of LBS in mobile.

- Impact of mobile marketing in the retail sector during COVID 19.

\section{Research Approach and Design}

This is an exploratory study, which aims to explore the impact of location-based marketing on the retail sector of the Al Batinah region in the Sultanate of Oman. The study proposes to adopt a mixed approach where both qualitative as well as quantitative methods, will be utilized. Data collection and sorting are done based on Quantitative methods.

In order to get insights into the factors, Qualitative research methods are adopted which brings out social and cultural phenomenon, the exploratory research is a fact-finding study that involves adequate and accurate interpretation of findings.

The survey method is appropriate and it enables the researcher in the formulation of generalizations. Questionnaire surveys and interviews are used in the research.

Sources of Data and Unit of Analysis

Primary and Secondary data were used. The first source is through a structured questionnaire. In addition, the second source of data is being collected from books, journals, and websites. 


\section{TOOLS FOR ANALYSIS}

A structured questionnaire with Closed-ended questions will be used to collect data from various SME's such as retail sectors and service sectors. We have used the Likert scale (five-point scale) in the attached questionnaire.

\section{Sample Design}

The sample population for the study will include the retailers and service sectors of the Al Batinah region. The study proposes to follow a convenient sampling method for the collection of data from the population.

\section{Data Analysis and Interpretation}

To satisfy the study objective and arrive at the study findings statistical tools such as Excel analysis.

Table 1 shows the nationality of respondents. It is noted that about $76 \%$ of target business units are either owned or managed by non-Omanis.

Table 1: Nationality

\begin{tabular}{lccc}
\hline & Frequency & Percent & Cumulative Percent \\
\hline Omani & 5 & 23.81 & 23.81 \\
Non-Omani & 16 & 76.19 & 100 \\
\hline
\end{tabular}

Table 2 shows that the different sorts of specialty units were focused on for the examination. There are ten sorts of specialty units recognized for the study. The three kinds of specialty units, for example, Coffee shops and cafés, retailers, and versatile shops establish over half of respondents.

Table 2: Business categories

\begin{tabular}{lccc}
\hline & Frequency & Percent & Cumulative Percent \\
\hline Mobile shop & 3 & 14.29 & 14.29 \\
Coffee Shop \&Rest & 5 & 23.82 & 38.11 \\
Retailer & 4 & 19.05 & 57.16 \\
Car showroom & 1 & 4.76 & 61.92 \\
Apparels & 1 & 4.76 & 66.68 \\
Clinic & 1 & 4.76 & 71.44 \\
Service Centre & 2 & 9.52 & 80.96 \\
Gift shop & 1 & 4.76 & 85.72 \\
franchisee & 2 & 9.52 & 95.24 \\
Tours \& travels & 1 & 4.76 & 100 \\
\hline
\end{tabular}

Table 3 shows the percentage of business units that use any LBM tools in their business. Around $90 \%$ of business units use any kind of LBM tool for their business.

Table 3: LBM in Business

\begin{tabular}{lccc}
\hline & Frequency & Percent & Cumulative Percent \\
\hline Yes & 19 & 90.48 & 90.48 \\
No & 02 & 9.52 & 100 \\
\hline
\end{tabular}

Table 4 unveils the significant LBM instruments utilized by different specialty units. Web-based media is the first and most significant LBM device utilized by most of the specialty units. Approximately, $76 \%$ of firms utilize online media for advancing their business during the Coronavirus pandemic. Furthermore, the google map is the second driving LBM instrument with $14 \%$ lastly SMS with $10 \%$. From this analysis, it is very clear that various social media platforms are used by many firms to promote their business.

Table 4: LBM tools used in a business during the pandemic

\begin{tabular}{lccc}
\hline & Frequency & Percent & Cumulative Percent \\
\hline Social media & 16 & 76.19 & 76.19 \\
SMS & 02 & 9.52 & 85.71 \\
Google Map & 03 & 14.29 & 100 \\
\hline
\end{tabular}

Table 5 discusses the expectation of customers from business units in terms of online experience/ marketing. $29 \%$ of firms said that customers are looking for cash on delivery services. And the second major expectations are online order and delivery and resolving complaints and troubleshooting. Online order, cash on delivery, and customer services are the three major areas are looked upon by customers in terms of online services from business units.

Table 5: Expectation of customers from business units during the pandemic

\begin{tabular}{lccc}
\hline & Frequency & Percent & Cumulative Percent \\
\hline Online order and delivery at doorsteps & 5 & 23.81 & 23.81 \\
Cash on delivery & 6 & 28.57 & 52.38 \\
\hline
\end{tabular}




\begin{tabular}{llcc}
\hline Click and collect. & 3 & 14.29 & 66.67 \\
Complaints and troubleshooting & 5 & 23.81 & 90.48 \\
Repair and Maintenance & 2 & 9.52 & 100 \\
\hline
\end{tabular}

Table 6 shows that only 14\% of business units were using any kind of LBM tools used very regularly and 33\% of business units used LBM tools very often. It is noted that around $47 \%$ of business firms were using and aware of various LBM tools.

$23.8 \%$ of business organizations were using any kind of LBM tools sometimes whereas $14 \%$ never used any LBM tools before the pandemic. This information will help us to understand the impact of the pandemic on LBM strategies.

Table 6: LBM tools used by business units before the pandemic

\begin{tabular}{lccc}
\hline & Frequency & Percent & Cumulative Percent \\
\hline Always & 3 & 14.3 & 14.3 \\
Often & 7 & 33.3 & 47.6 \\
Sometimes & 5 & 23.8 & 71.4 \\
Rarely & 3 & 14.3 & 85.7 \\
Never & 3 & 14.3 & 100 \\
\hline
\end{tabular}

As we know that mobile phones are the key and convenient instrument used for connecting with customers especially during the covid 19 pandemic. Around $24 \%$ of firms use mobile phones always as an instrument and $38 \%$ of firms use them very often. There are no firms never use a mobile phone as an instrument to connect with their customers.

Table 7: Mobile phone as an LBM tool

\begin{tabular}{lccc}
\hline & Frequency & Percent & Cumulative Percent \\
\hline Always & 5 & 23.81 & 23.81 \\
Often & 8 & 38.10 & 61.91 \\
Sometimes & 5 & 23.81 & 85.72 \\
Rarely & 3 & 14.28 & 100 \\
Never & 0 & 0 & 100 \\
\hline
\end{tabular}

Table 8 show that WhatsApp is the number 1 social media used by business firms as an LBM tool. After WhatsApp, Instagram, Facebook and google possess the second to fourth respectively. WhatsApp, Instagram, and Facebook are the three major social media platforms used by business firms to connect with their customers.

Table 8: The effective social media used during the pandemic

\begin{tabular}{lll}
\hline & Score & Rank \\
\hline Google & 30 & 4 \\
Instagram & 87.5 & 2 \\
Snapchat & 5 & 6 \\
WhatsApp & 120 & 1 \\
Facebook & 67.5 & 3 \\
Twitter & 7.5 & 5 \\
\hline
\end{tabular}

Table 9 shows the impact of social media used by business firms to connect with their customers. The above analysis explains that almost $24 \%$ of business units use social media to connect with their customers and $38 \%$ and $24 \%$ of business units use social media very often and sometimes respectively.

Table 9: Impact of social media to connect with customers

\begin{tabular}{lccc}
\hline & Frequency & Percent & Cumulative Percent \\
\hline Always & 5 & 23.81 & 23.81 \\
Often & 8 & 38.10 & 61.91 \\
Sometimes & 5 & 23.81 & 85.72 \\
Rarely & 3 & 14.28 & 100 \\
Never & 0 & 0 & 100 \\
\hline
\end{tabular}

\section{CONCLUSION}

Today, social media platforms play an important role in the Location-Based marketing of various retail sectors such as SME's and these platforms play a major role in helping retailers to make decisions whether they wish to market their products by using this platform or not. Overall finding and evaluation part of the journey, out of a brand's own characteristics the social media feeds, search engines, and influencers are popular ways for shoppers to gain product inspiration. From the buyers perceptive of the journey, nowadays there are many new types of purchases points are available for them to select the different types of products and services.

Recently Mobile wallets are behind e-mail as a place to select the suitable purchases. Most of the sellers are promoting the product sales through social media. Customers are making use of various touch panels during the purchase but there is a 
remarkable disconnect between the companies. In our study, most of the product sellers are providing compatible interactions between all departments. However, 58\% of shop keepers are reporting that they feel like the customers are communicating with separate departments and not one company. And when it comes to service issues, the majority of customers expect all the representatives must communicate the same information about the products and services, but some of the shoppers are saying that they must re-explain issues.

In the present environment, customer services and unified channels are more important than ever, During the initial stages of COVID-19 spread, most of the needless businesses are shutdown their business to help the community and help to reduce the spread. It creates the opportunity for the retailers and shoppers to make use of this location-based service marketing strategy is one of the best solutions to grow their business further. It means that retailers and shoppers believe strongly in a digital-only reality. Location-based marketing strategies might help to increase the efficiency and effectiveness of various marketing activities. Therefore, the effective application of social media should be a part of any business's marketing strategy. For example, social media visuals, content, promotional activities, and use of opinion leader influence should be deployed to positively influence the buying behaviors of consumers.

\section{RECOMMENDATIONS}

That the scope of the research is expanded, and the experiment was conducted on market - collaborations across the various teams and keeps the shoppers and marketers engaged with applications.

- To intensify and increase research and literature related to engage Customers with the understanding of and accept your customers, make use of the live data to effectively understand their present situation and current requirements of the customers.

- Doing large-scale statistics on most of the platforms used to exploit this data and promote the LBS with personalizing the electrical and digital Communications - Increase the usage of digital channel adoptions will help them to deliver the right message, to the right person, at the right time.

- Planning for high building facility and infrastructure, to provide the need and the requirement of the LBS to optimize the budget allocation and make on-time decisions to downsize the negative impact and to view unified marketing performance.

- During this COVID 19 pandemic period, we have identified that every company must be focused on three important stages of response: reopening of workplaces and stabilizing the company, and grow your business to at last when we emerge from this crisis.

- There is no doubt that LBS marketing will be a competitive business for the upcoming years to come. Top management should work hard in data mining to accurately depict consumers and at the same time create marketing types, but the current focus is still on mobile advertising and Location-based marketing.

- Currently, most of the retailers are facing numerous problems such as lack of media selection basis, immature data management, and delivery technology, but in the next few years, business owners will invest more resources and forces to conquer the commercialization of mobile terminal, and mobile marketing will enter the fast track. Retail Business owners \& SME's also want to clear positioning for the brand, to foster strengths and circumvent weaknesses.

- These research paper findings highlight the growing importance of social media as a marketing tool that has occurred since the declaration of the COVID-19 pandemic. As such, the findings illustrate the impact that social media can have on consumer decision-making processes.

\section{REFERENCES}

1. Akdağ, S.G, \& Ergen, A. (2020). Role of location-based mobile apps in city marketing: Beşiktaş as a studentfriendly district. Journal of Location Based Services, 14(2), 49-70. https://doi.org/10.1080/1 7489725.2020.1788184

2. Banerjee, S., Xu, S., \& Johnson, S. D. (2021). How does location-based marketing affect mobile retail revenues? The complex interplay of delivery tactic, interface mobility and user privacy. Journal of Business Research, 130, 398-404.

3. Bauer, Christine \& Strauss, Christine. (2016). Location-based advertising on mobile devices: A literature review and analysis. Management Review Quarterly, 66. 159-194.

4. Bedgood, L. A. R. I. S. A. (2020, July 20). Changes in Consumer Behavior During COVID-19. Business 2 Community. https://www.business2community.com/consumer-marketing/changes-in-consumer-behavior-duringcovid-19-02331693

5. Bernritter, S.F., Ketelaar, P.E. \& Sotgiu, F. (2021). Behaviorally targeted location-based mobile marketing. J. of the Acad. Mark. Sci., 49, 677-702.

6. Bertini, M., \& Aydinli, A. (2020). Consumer Reactance to Promotional Favors. Journal of Retailing, 96(4), 578589.

7. Chen, Jengchung \& Su, Bo-chiuan \& Yen, David. (2014). Location-based advertising in an emerging market: A study of Mongolian mobile phone users. Int. J. of Mobile Communications, 12. 291 - 310. 
8. Fong, N. M., Fang, Z., \& Luo, X. (2015). Geo-Conquesting: Competitive Locational Targeting of Mobile Promotions. Journal of Marketing Research, 52(5), 726-735. https://doi.org/10.1509/jmr.14.0229

9. Guido, Jorge Carlos Fiestas Lopez \& Tuzovic, Sven (2018) Leveraging location-based services to disrupt retail showrooming. In 2018 Australian and New Zealand Marketing Academy (ANZMAC) Conference, 2018-12-03 2018-12-05.

10. Handly, B. (2019). Learn how the different types of location-based marketing tactics work so you can utilize them efficiently for your brand.

11. He, Wenbo \& Liu, Xue \& Ren, Mai. (2011). Location Cheating: A Security Challenge to Location-Based Social Network Services. Proceedings - International Conference on Distributed Computing Systems.

12. Jaradat, A., Mohamad, N. A., Asadullah, A., Ebrahim, S. (2015). Issues in Location Based Marketing: A Review of Literature System Information. International Journal of Scientific and Research Publications, 5(1).

13. Khan V.-J., Ketelaar P., van 't Riet J., Konig R., Rozendaal E.,Batalas N. \& Markopoulos P., (2017). Does location congruence matter? A field study on the effects of locationbased advertising on perceived AD intrusiveness, relevance \& value. Computers in Human Behavior, 73, 695-668. https://doi.org/10. 1016/j.chb.2017.03.003

14. Law, R., Chan, I.C.C \& Wang, L. (2018). A comprehensive review of mobile technology use in hospitality and tourism. Journal of Hospitality Marketing \& Management, 27(6), 626-648.

15. Moody, M. (2015). Analysis of Promising Beacon Technology for Consumers. Elon Journal of Undergraduate Research in Communications, 6(1). Retrieved from http://www.inquiriesjournal.com/a?id=1136

16. Sperling, D \& Gordon, D. (2009). Two Billion Cars: Driving Toward Sustainability.

17. Tsekouras, D., Dellaert, B. G. C., Donkers, B., \& Häubl, G. (2019). Product set granularity and consumer response to recommendations. Journal of the Academy of Marketing Science, 48(2), 186-202.

18. Tussyadiah, Iis. (2012). A Concept of Location-Based Social Network Marketing. Journal of Travel \& Tourism Marketing, 29, 205-220.

19. Uphaus, P., Beringer, B., Siemens, K., Ehlers, A., \& Rau, H. (2021). Location-based services - the market: success factors and emerging trends from an exploratory approach. Journal of Location Based Services, 15(1), 126.

20. Van de Sanden, S., Willems, K. \& Brengman, M. (2019). In-store location-based marketing with beacons: from inflated expectations to smart use in retailing. Journal of Marketing Management, 35(15-16), 1514-1541.

21. Yim, J., Ganesan, S., Kang, B.H. (2017). Location-Based Mobile Marketing Innovations. Mobile Information Systems, 2017, Article ID 1303919.

\section{The impact of LBS Marketing strategies on retail sectors of Al Batinah during post COVID 19 Pandemic}

Location-based marketing allows organizations to target consumers at person level with online or offline messaging based on their physical location. Using location data, marketing teams are able to reach consumers based on qualifiers like proximity to a store, events happening in their region, and more.

Location-based marketing has proven effective across customer lifecycles - from discovery and purchase, to engagement and retention. When used properly, location-based marketing allows marketers to hone in on specific customer segments with targeted offers, while improving customer experience for a population that increasingly values instant gratification. For example, location-based marketing may alert a prospect that a product they have been considering is stocked in a nearby store, allowing them to pick it up right away.

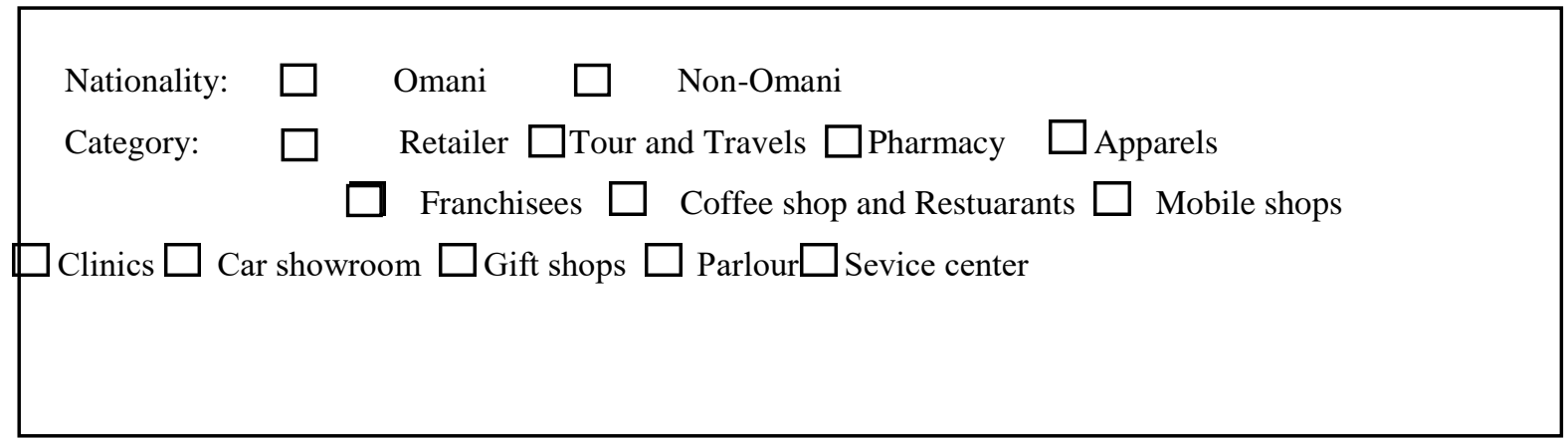
1. Do you use LBM (Location Based Marketing) for your business?
○ Yes
$\circ$ No

2. If yes, which of the following LBM tools are used in your business?

- Search engines/Google map

- Social medias

- Website

- SMS

○ $\quad$ E Mail 
Other specify

\section{Answer the following questions:}

3. Expectation of customers from you during pandemic:

1) Strongly Disagree 2) Disagree 3) Neutral 4) Agree 5) Strongly agree

\begin{tabular}{lllllll}
\hline S.No & Item & 1 & 2 & 3 & 4 & 5 \\
\hline 1 & On line order and delivery at door steps & & & & & \\
\hline 2 & Cash on delivery & & & & \\
\hline 3 & Click and Collect & & & & \\
\hline 4 & Complaints and trouble shooting & & & & \\
\hline 5 & Repair and Maintainance & & & & \\
\hline
\end{tabular}

\section{Answer Following Question:}

1) Always 2) Often 3) Sometimes 4) Rarely 5) Never

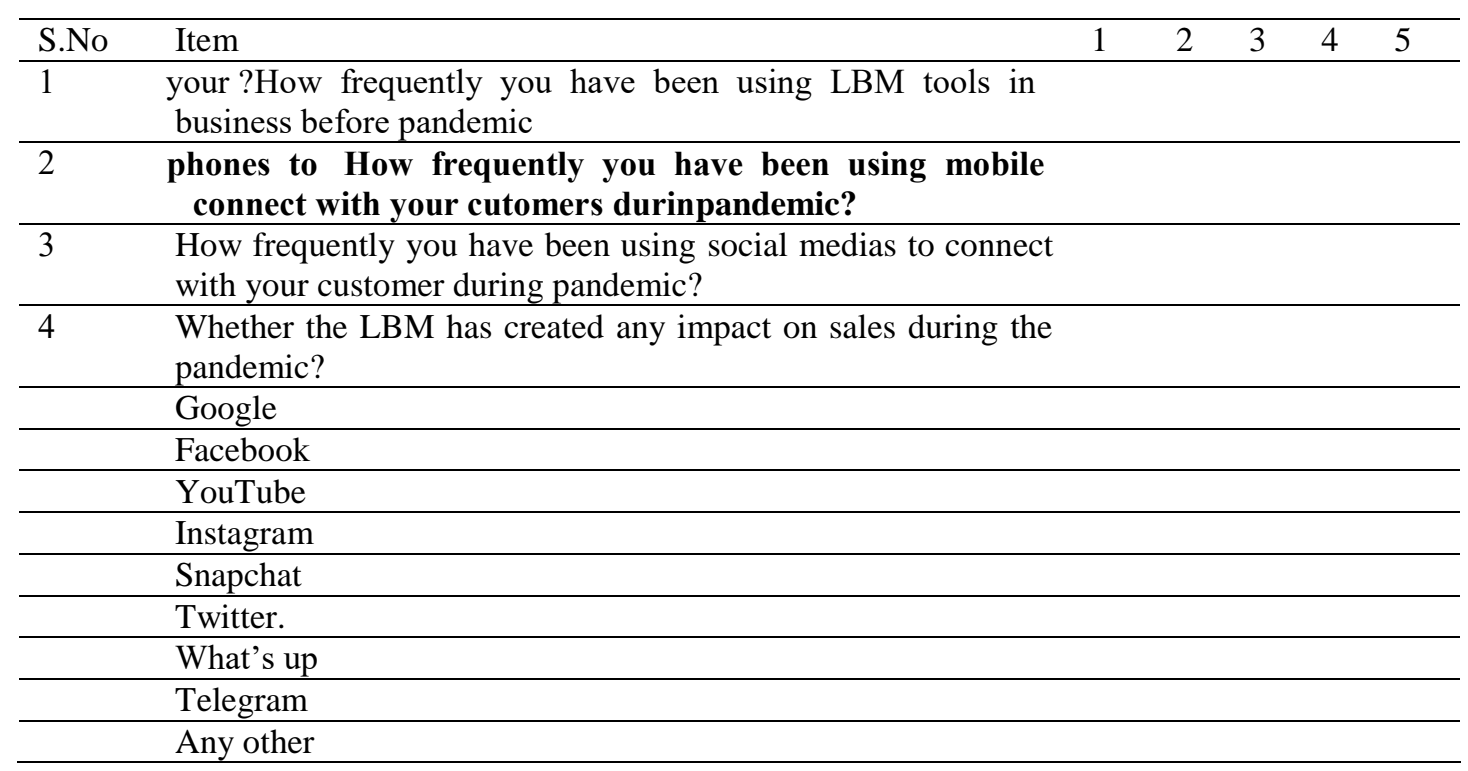

5. Do you provide offers or schemes to your customers by using on-line services?

$\circ$ Yes

$\circ$ No

\begin{tabular}{lll}
\hline 6. & $\begin{array}{l}\text { Which of the following social media is more effective to } \\
\text { increase the sales during the pandemic? }\end{array}$ & $\begin{array}{l}\text { Tick the right } \\
\text { choices }\end{array}$ \\
\hline Google & \\
\hline Facebook & \\
\hline YouTube & \\
\hline Instagram & \\
\hline Snapchat & \\
\hline Twitter. & \\
\hline What's up & \\
\hline Telegram & \\
\hline Any other
\end{tabular}

\section{Answer Following Question:}

1) Always 2) Frequently3) Sometimes 4) Rarely 5) Never

\begin{tabular}{lllllll}
\hline S.No & Item & 1 & 2 & 3 & 4 & 5 \\
\hline 1 & $\begin{array}{l}\text { Location based(Do you think LBM } \\
\text { is an effective tool to attract and )Marketing } \\
\text {.retain customers during and post pandemic }\end{array}$ & & & & & \\
&
\end{tabular}

